\title{
THE STUDENTS' EYESIGHT: THE EFFECTIVENESS OF LEARNING-BASED APPLICATIONS ON ELT IN PANDEMIC ERA
}

\author{
Andi Bulkis Maghfirah Mannong \\ Universitas Negeri Surabaya \\ andi.19006@mhs.unesa.ac.id
}

\begin{abstract}
The emergence of the Covid-19 has given a significant effect that inflicted policy changes in various sectors, including in the education field. The most basic policy is changing the students' way to learn from what is usually done in the classroom (face to face) to online learning. As this condition, the implementation of learning-based applications has a necessary role in supporting online learning, includes English Language Teaching (ELT). This study aimed to analyze the students' experience in utilizing learning-based applications in learning English and the barriers faced by them. As for some of the applications most commonly used are Zoom, Google Meet, Google Classroom, and WhatsApp. Besides, this study was also conducted to determine which application is the most effective used in ELT during online learning. This research used descriptive quantitative, where the sample was the seventh-semester students in the English department at one of the private universities in Makassar. The data was collected used questionnaire and the data analysis technique used descriptive statistics. The result of this study showed that the use of those four applications helped the students to adapt to the pandemic condition. Besides helping students to learn English virtually, it also improves the students' digital literacy. Although, there were some obstacles in utilizing some applications faced by them, such as limited quota, unstable network, complicated in use, and not focus during the learning process. Among the four applications above, the most effective application based on the students' response was Whatsapp. This application helps the students to develop their language proficiency through natural interaction. Moreover, it makes the students easier in learning English as the delivery of material is systematic and structured. Students also have more time to understand the material by rereading the material that has been delivered.
\end{abstract}

Keywords: The Students' Eyesight, Effectiveness, Zoom, Google Meet, Google Classroom, WhatsApp, ELT, Covid-19

\section{A. INTRODUCTION}

he emergence of the Covid-19 pandemic has given a significant impact that inflicted
policy changes in various sectors, including in the education field. This pandemic
situation forces the Indonesian government through the Ministry of Education and

Culture of the Republic of Indonesia to provide a policy on a series of learning in the Covid-19 emergency, where learning activities that are generally carried out in classrooms are conventionally transferred to learning from home or learning online classes. This has done so that the world of education would not be badly affected in the midst of the continuing pandemic.

The implementation of online learning or virtual Classroom with technology is used to support distance learning for students and teachers, where the teachers provide teaching materials in the form of digital content that can be accessed, stored, and shared via the internet 
which can be accessed anytime and anywhere. The most prominent characteristic of learning online is providing convenience and flexibility for teachers and students especially for determine online learning schedules without prioritizing time and location (Bower, et.al., 2015).

Moreover, it provides facilities for teachers to upload teaching materials so that they can be downloaded directly by students who are members of the class. Technology as a medium in teaching and learning activities can make learning activities more interesting, innovative so that they can provide motivation for students to be active in learning activities (Dharmawati, 2017). Furthermore, Roida and Yuni (2020) claim that information technology is very helpful in the process of learning online or online during the Corona Covid-19 virus outbreak, then a whole process of teaching and learning activities can be done well. Also, it makes the learning activities not monotonous.

The acceleration of educational technology transformation due to the Corona pandemic has made various platforms launch various online learning applications to support distance learning. The implementation of the virtual classroom can be supported by using applications or platforms- based learning. There some various applications such as WhatsApp, Zoom, Google Classroom, and Google Meet.

Google Classroom is a foyer of online mixed learning applications that enables teaching and learning activities to be more productive and meaningful by simplifying assignments, increasing collaboration, and fostering communication. Teachers can create classes, give assignments, send feedback, and see everything in one place. While, Zoom is an application that provides remote conferencing services by combining video conferencing, online meetings, chat, to mobile collaboration.

In addition, WhatsApp has a great influence in the education world today. It has been used extensively by the teachers for teaching and learning purposes in the wake of the Covid19 virus. It is used to post the task, notes, instructions, and assignment. This application is helpful due to the special features like videos, audio, text messaging and sending images to each other (Walker, 2020).

Based on the explanation above, the researcher interested to investigate how the utilization of the applications; WhatsApp, Zoom, Google Classroom, and Google Meet in an online class on English language teaching and learning. The problem of research can be formulated into:

1. How do the utilization of WhatsApp, Zoom, Google Classroom, and Google Meet in online class in English language teaching and learning? 
2. What are the barriers commonly faced by the students in utilizing WhatsApp, Zoom, Google Classroom, and Google Meet during the English language teaching and learning process?

3. Which application is the most effective used in online class in English language teaching and learning based on the students' experience?

\section{B. REVIEW OF LITERATURE}

\section{Online Learning}

Based on government regulations, teaching and learning activities that are usually carried out in schools are converted into online learning. This is done so that learning activities can continue in the current pandemic situation. The online learning system is a learning system without face to face directly between teachers and students but carried out online using the internet network. Learning is carried out anytime and anywhere without having to meet face to face. (Evans and Sadler, 2008; Albitar, 2020).

Moreover, with the use of technology that is supported by the internet, online learning activities can take place properly. The advancement of information technology that has developed rapidly and is supported by the use of internet facilities makes activities possible at home, at school, and in the community (Wahyu, 2020). The learning system is carried out through personal computers, mobile phones, and laptops that are connected to an internet network connection. To support online learning, teachers can take advantage of online applications, such as WhatsApp, Zoom, Google Classroom, Google Meet, or other applications as learning media.

\section{WhatsApp}

WhatsApp is one of the most popular social media which is used by Indonesian people. Almost all humans use WhatsApp as daily social media (Khusaini, et.al., 2017). In the context of the teaching and learning process, WhatsApp can help the students to interact with each other by using English whenever and wherever. Besides that, WhatsApp also can help the students to increase their language skills like speaking, writing, reading, and listening (D'Eca, 2003).

Furthermore, in facilitating the process of teaching and learning English, the teacher can use WhatsApp as instructional media (Kheryadi, 2017). By this application, the teacher and students can send and share English messaging, pictures, documents, and text materials. The user can send messages to individuals or groups in the form of text messages, photos, audio files, video files, and links of the web address to be accessed (Bouhnik \& Deshen, 2014). 
Thus, this application is effective media used to facilitate the process of teaching and learning English.

\section{Google Classroom}

Google Classroom is available to anyone with Google Apps for Education, a free productivity tool including Gmail, Drive, and Docs. Google Classroom is considered to be one of the best platforms in a pandemic like this for distance learning, online learning, or virtual classes that can maximize teacher workflow. In implementing distance learning, the utilization of Google Classroom can help the teachers in providing the learning materials, assignments, and assessments to the students $(\mathrm{Ni}, 2020)$. This application provides a set of powerful features that are ideal tools for teachers to use with students. Classes help teachers give time, keeping classes organized. and can also improve communication with students.

\section{Zoom}

Online or distance learning tools are changing the way we learn. One of the new conference room solutions based on the original software is Zoom technology. Zoom is a cloud-based service that offers meetings and webinars and provides content sharing and video conferencing capabilities. Moreover, Zoom is an easy and reliable cloud platform for video and audio conferencing, collaboration, chat, and webinars across mobile devices, desktops, telephones, and room systems.

The Zoom feature allows the English teacher to explore and assess four skills. Zoom allows English teachers to present their lesson content in a variety of ways (Guzacheva, 2020). Zoom's screen sharing can give English teachers a great opportunity to develop students' intercultural skills by sharing interesting materials such as videos and articles, and presentations. During lessons and after watching them, the English teacher can encourage students to use active questions to analyze and evaluate their learning. Teachers can also ask students to reflect on their lesson by recording a video and sharing it.

\section{Google Meet}

One of the applications that can also be used in teaching and learning English is Google Meet. This application is a video conferencing service developed by Google. The utilization of Google Meet as media in language teaching and learning process has necessary roles in increasing the students' four language skills, namely speaking, reading, listening, and writing (Fakhruddin, 2018). 
Additionally, here are some previous researches that conducted the use of platforms/ applications in online learning:

Riyanti and Muslimah (2018) conducted the research to identify the students' responses toward the use of Google Classroom in teaching the English Language. This study only focused on the use of one application in teaching the English language, moreover, it only focuses on the effectiveness of Google Classroom application as media in teaching language. While the present study focused on the use of four applications (WhatsApp, Zoom, Google Classroom, and Google Meet) and it not only focused on the use and the effectiveness of these applications, but also on the barriers faced by the students in utilizing these applications during teaching and learning process.

Furthermore, in Cakrawati (2017) study, it aims to find the students' perceptions on the use of online learning platforms in the EFL Classroom. This study focused on the use of Moodle and Quipper platforms and the sample was the students in junior and high level while the present study focused on students in higher education level.

Based on the description above, this study focused on how the students' perceptions and experiences on the implementation of WhatsApp, Zoom, Google Classroom, and Google Meet in an online class on English language teaching and learning, both in their use and the constraints faced by the students during teaching and learning process through these applications.

\section{METHOD}

This present study used descriptive quantitative research to identify the utilization of learning-based applications in learning English and the barriers faced by the students and to determine which application is the most effective and suitable for students used in ELT during online learning.

\section{Respondents}

The population of this study was all graduate students of the English Department who are studying at one of the private university in Makassar. There were thirty students who were participated as the sample in this study in which they were taken randomly. The sample was the students who had utilized WhatsApp, Zoom, Google Classroom, and Google Meet in the English teaching and learning process. 


\section{Instruments}

In collecting the data, the questionnaire was used in this study which the total of items was 40. It consisted of 24 positive statements and 16 negative statements, and it was put in five categories of the Likert Scale, Strongly Agree, Agree, Neutral, Disagree, Strongly Disagree. The questionnaire was concerning the use of Zoom, Whatsapp, Google Classroom, and Google Meet applications in teaching and learning English. It was done to know the students' perception of the utilization of applications used in online learning, the barriers faced by them, and to determine the most effective and suitable application for students' needs and situations based on their experience.

\section{Procedures}

Data collection was carried out using a questionnaire which included the use of the WhatsApp, Zoom, Google Classroom, and Google Meet applications as media in learning and teaching English, and difficulties or obstacles encountered during the learning process through these four media. The questionnaires were sent online to the students in the form of a google form. Furthermore, this data was analyzed using descriptive statistics.

\section{Data analysis}

The data analysis used in this study was descriptive statistics. It was used to gain information concerning the students' responses toward all items in the questionnaire. In other words, the descriptive statistic used to perceive the students' responses toward the utilization of WhatsApp, Google Classroom, Zoom, and Google Meet applications as media in the English teaching and learning process during the Covid-19 pandemic.

\section{FINDINGS AND DISCUSSION}

\section{The Utilization of Learning-Based Applications}

After analyzing and comparing the data concerned to the students' responses toward the utilization of learning-based applications such as WhatsApp, Google Classroom, Zoom, and Google Meet, it was found different responses toward the use of the four applications as shown in table $1,2,3$ and 4.

Table 1. The utilization of WhatsApp

\begin{tabular}{|c|c|c|c|c|c|c|}
\hline \multirow[t]{2}{*}{ No. } & \multirow[t]{2}{*}{ Statement } & \multicolumn{5}{|c|}{ WhatsApp } \\
\hline & & SA & $\mathbf{A}$ & $\mathbf{N}$ & $\mathbf{D}$ & SD \\
\hline 1. & WhatsApp is easy to access. & $\begin{array}{c}28 \\
(93.3 \%)\end{array}$ & 2 & & & \\
\hline
\end{tabular}




\begin{tabular}{|c|c|c|c|c|}
\hline & & & $(6.7 \%)$ & \\
\hline 2. & $\begin{array}{l}\text { It is compatible to access } \\
\text { WhatsApp on both cell phone } \\
\text { and laptop. }\end{array}$ & $\begin{array}{c}23 \\
(76.7 \%)\end{array}$ & $\begin{array}{c}7 \\
(23.3 \%)\end{array}$ & \\
\hline 3. & $\begin{array}{l}\text { The given materials are easy to } \\
\text { comprehend. }\end{array}$ & $\begin{array}{c}20 \\
(66.7 \%)\end{array}$ & $\begin{array}{c}9 \\
(30 \%)\end{array}$ & $\begin{array}{c}1 \\
(3.3 \%)\end{array}$ \\
\hline 4. & $\begin{array}{l}\text { It is easy to understand the } \\
\text { instruction of the assignment } \\
\text { given by the teacher through } \\
\text { WhatsApp. }\end{array}$ & $\begin{array}{c}20 \\
(66.7 \%)\end{array}$ & $\begin{array}{c}10 \\
(33.3 \%)\end{array}$ & \\
\hline 5. & $\begin{array}{l}\text { The use of WhatsApp makes me } \\
\text { enthusiastic in the teaching and } \\
\text { learning process. }\end{array}$ & $\begin{array}{c}8 \\
(26.7)\end{array}$ & $\begin{array}{c}22 \\
(73.3 \%)\end{array}$ & \\
\hline 6. & $\begin{array}{l}\text { This application helps me to } \\
\text { improve my digital literacy. }\end{array}$ & $\begin{array}{c}18 \\
(60 \%)\end{array}$ & $\begin{array}{c}12 \\
(40 \%)\end{array}$ & \\
\hline
\end{tabular}

In table 1, it showed that the utilization of WhatsApp got very positive responses where all of the students argued that this application was easy to access and it was compatible to access in both laptop and cell phone. This application made the students enthusiastic in the teaching and learning process. They feel excited to study English through WhatsApp as they can always connect with their friends and teachers anytime and anywhere, thus they study in a fun way (Miming, 2019). Moreover, it also helped the students to improve their digital literacy. Furthermore, by using this application as media in teaching and learning English, most of the students $(96,7 \%)$ opined that it was easier to comprehend the materials and understand the assignment instruction given by the teachers. This application offers a great chance for the students to express their feelings, thoughts, and ideas with others more easily and efficiently Kheryadi (2017).

Table 2. The utilization of Google Classroom

\begin{tabular}{|c|c|c|c|c|c|c|}
\hline \multirow[t]{2}{*}{ No. } & \multirow[t]{2}{*}{ Statement } & \multicolumn{5}{|c|}{ Google Classroom } \\
\hline & & SA & $\mathbf{A}$ & $\mathbf{N}$ & $\mathbf{D}$ & SD \\
\hline \multirow[t]{2}{*}{11.} & Google Classroom is easy to & 20 & 7 & & 3 & \\
\hline & & $(66.7 \%)$ & $(23.3 \%)$ & & $(10 \%)$ & \\
\hline \multirow[t]{2}{*}{12.} & It is compatible to access & 14 & 16 & & & \\
\hline & $\begin{array}{l}\text { Google Classroom on both cell } \\
\text { phone and laptop. }\end{array}$ & $(46.7 \%)$ & $(53.3 \%)$ & & & \\
\hline \multirow[t]{2}{*}{13.} & $\begin{array}{l}\text { The given materials are easy to } \\
\text { comprehend. }\end{array}$ & 4 & 18 & & $\begin{array}{c}8(26.7 \\
\%)\end{array}$ & \\
\hline & & $(13.3 \%)$ & $(60 \%)$ & & & \\
\hline \multirow[t]{2}{*}{14.} & $\begin{array}{l}\text { It is easy to understand the } \\
\text { instruction of assignments given }\end{array}$ & & 14 & 6 & 10 & \\
\hline & $\begin{array}{l}\text { by the teacher through Google } \\
\text { Classroom. }\end{array}$ & & $(46.7 \%)$ & $(20 \%)$ & $(33.3)$ & \\
\hline
\end{tabular}




\begin{tabular}{|c|c|c|c|c|c|}
\hline 15. & $\begin{array}{l}\text { The use of Google Classroom } \\
\text { makes me enthusiastic in the } \\
\text { teaching and learning process. }\end{array}$ & & (33.3) & $\begin{array}{c}5 \\
(16.7 \%)\end{array}$ & $\begin{array}{c}15 \\
(50 \%)\end{array}$ \\
\hline 16. & $\begin{array}{l}\text { This application helps me to } \\
\text { improve my digital literacy. }\end{array}$ & $\begin{array}{c}12 \\
(40 \%)\end{array}$ & $\begin{array}{c}18 \\
(60 \%)\end{array}$ & & \\
\hline
\end{tabular}

Based on the data above, it showed that the utilization of Google Classroom as media in the English teaching and learning process also got positive responses from the students where all of the students claimed that this application was compatible to access in both laptop and cell phone. Moreover, most of the students strongly agree that this application was easy to access, and by this application, the students were easy to comprehend the given materials. This application helps the teacher to organize the online class take advantage of time and improve the quality of communication with students (Latif, 2016). Nevertheless, there were only 46,7\% of students who agreed that it was easy to understand the assignment instructions given by the teachers through this application, $33,3 \%$ of students disagree about it and the rest choose neutral.

Table 3. The utilization of Zoom

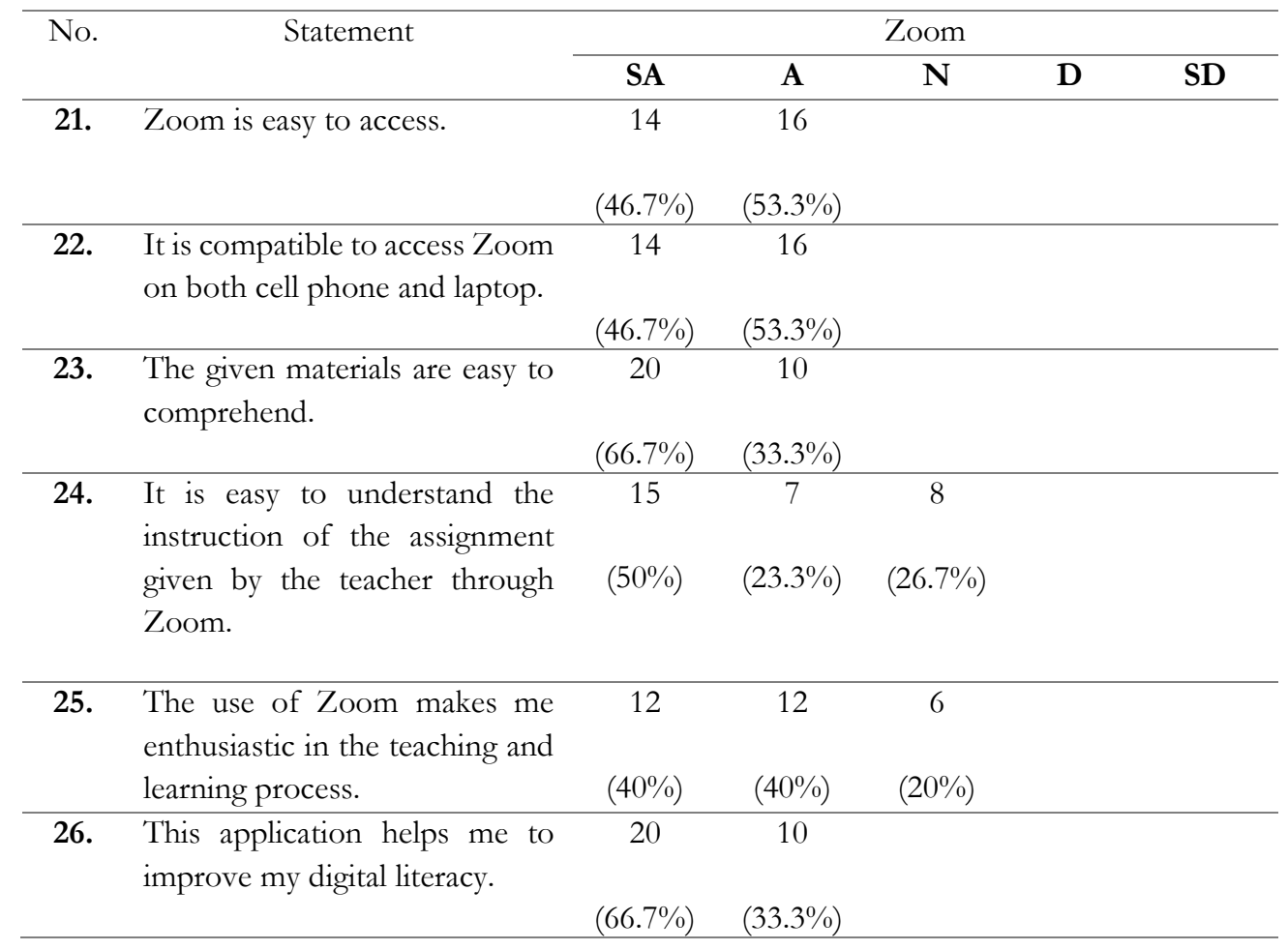

As WhatsApp, Zoom also got very positive responses from the students where all of the students argued that this application was easy to access and it was compatible to access this application in both cell phone and laptop. Furthermore, by utilizing this application as media in the English learning and teaching process, the students were easy to comprehend the given 
materials. Still, this application also helped them in improving their digital literacy. Besides, most of the students felt they could understand easily the assignment instructions given by the teacher $(73,3 \%)$ and felt enthusiastic in the teaching and learning process $(80 \%)$. This is in line with Guzacheva (2020) which denotes that Zoom motivates English teachers to annotate the screens they share, thus making lessons more interactive.

Table 4. The utilization of Google Meet

\begin{tabular}{|c|c|c|c|c|c|c|}
\hline \multirow[t]{2}{*}{ No. } & \multirow[t]{2}{*}{ Statement } & \multicolumn{5}{|c|}{ Google Meet } \\
\hline & & SA & $\mathbf{A}$ & $\mathbf{N}$ & $\mathbf{D}$ & SD \\
\hline \multirow[t]{2}{*}{31.} & Google Meet is easy to access. & 10 & 15 & 3 & 2 & \\
\hline & & $(33.3)$ & $(50 \%)$ & $(10 \%)$ & $(6.7 \%)$ & \\
\hline \multirow[t]{3}{*}{32.} & It is compatible to access & 12 & 18 & & & \\
\hline & Google Meet on both cell phone & & & & & \\
\hline & and laptop. & $(40 \%)$ & $(60 \%)$ & & & \\
\hline \multirow[t]{2}{*}{33.} & $\begin{array}{l}\text { The given materials are easy to } \\
\text { comprehend. }\end{array}$ & 10 & 14 & 6 & & \\
\hline & & $(33.3)$ & $(46.7 \%)$ & $(20 \%)$ & & \\
\hline 34. & $\begin{array}{l}\text { It is easy to understand the } \\
\text { instruction of the assignment } \\
\text { given by the teacher through } \\
\text { Google Meet. }\end{array}$ & $\begin{array}{c}15 \\
(50 \%)\end{array}$ & $\begin{array}{c}12 \\
(40 \%)\end{array}$ & $\begin{array}{c}3 \\
(10 \%)\end{array}$ & & \\
\hline 35. & $\begin{array}{l}\text { The use of Google Meet makes } \\
\text { me enthusiastic in the teaching } \\
\text { and learning process. }\end{array}$ & $(26.7)$ & $(26.7 \%)$ & $\begin{array}{c}2 \\
(6.7 \%)\end{array}$ & $\begin{array}{c}12 \\
(40 \%)\end{array}$ & \\
\hline 36. & $\begin{array}{l}\text { This application helps me to } \\
\text { improve my digital literacy. }\end{array}$ & $\begin{array}{c}20 \\
(66.7 \%)\end{array}$ & $\begin{array}{c}10 \\
(33.3)\end{array}$ & & & \\
\hline
\end{tabular}

Based on the data above, overall the utilization of Google Meet also got positive responses from the students, in which all of the students concurred that this application was compatible to access in both cellphone and laptop. Besides, it also improved the students' digital literacy. Moreover, most of the students concurred that by this application, the students could understand the given materials (80\%) and the assignment instruction (90\%) easily. Furthermore, most of the students also confirmed that this application was easy to access $(83,3 \%)$ and made the students enthusiastic in the teaching and learning process $(53,4 \%)$. Thus this application was also effective used in English Language teaching and learning. As Fakhruddin (2018) claims that the use of Google Meet as teaching media in English classroom can improve the students' skills, especially for speaking skill.

\section{The Barriers Faced by the Students in Utilizing Learning-Based Applications}


In utilizing these four applications (WhatsApp, Zoom, Google Classroom, and Google Meet) in the English language teaching and learning, there were some barriers faced by the students, such as the applications drained quota, the signal strength during teaching and learning process, complicated in using that made the students did not focus during the learning process.

Table 5 . The barriers faced by the students in utilizing WhatsApp

\begin{tabular}{|c|c|c|c|c|c|c|}
\hline \multirow[t]{2}{*}{ No. } & \multirow[t]{2}{*}{ Statement } & \multicolumn{5}{|c|}{ WhatsApp } \\
\hline & & SA & $\mathbf{A}$ & $\mathbf{N}$ & D & SD \\
\hline \multirow[t]{2}{*}{7.} & $\begin{array}{l}\text { The utilization of WhatsApp in } \\
\text { the teaching and learning }\end{array}$ & & & & 14 & 16 \\
\hline & process drains the quota. & & & & $(46.7 \%)$ & $(53.3 \%)$ \\
\hline \multirow[t]{2}{*}{8.} & $\begin{array}{l}\text { The signal strength is not stable } \\
\text { during the teaching and }\end{array}$ & & & & 18 & 12 \\
\hline & learning process. & & & & $(60 \%)$ & $(40 \%)$ \\
\hline \multirow[t]{2}{*}{9.} & $\begin{array}{l}\text { WhatsApp is complicated to } \\
\text { use. }\end{array}$ & & & & 2 & 28 \\
\hline & & & & & $(6.7 \%)$ & $(93.3 \%)$ \\
\hline \multirow[t]{2}{*}{10.} & $\begin{array}{l}\text { I often do not focus during the } \\
\text { learning process. }\end{array}$ & & 4 & & 18 & 8 \\
\hline & & & $(13.3 \%)$ & & $(60 \%)$ & $(26.7 \%)$ \\
\hline
\end{tabular}

Table 5 showed that there were no significant barriers faced by the students. When using WhatsApp, all of the students did not encounter this application drained their quota. Their signals also were stable during the English language learning and teaching process. Most of the users prefer to use WhatsApp since it allows to send message, image, video and audio with low fee (Rolve, 2013). Besides, this application was easy to use and apply. Moreover, through this application, most of the students $(86,7 \%)$ felt focus during the learning process, although there were $13,3 \%$ of students felt did not focus during the learning process.

Table 6. The barriers faced by the students in utilizing Google Classroom

\begin{tabular}{|c|c|c|c|c|c|c|}
\hline \multirow[t]{2}{*}{ No. } & \multirow[t]{2}{*}{ Statement } & \multicolumn{5}{|c|}{ Google Classroom } \\
\hline & & SA & $\mathbf{A}$ & $\mathbf{N}$ & $\mathbf{D}$ & SD \\
\hline \multirow[t]{3}{*}{17.} & The utilization of Google & & & 3 & 18 & 9 \\
\hline & Classroom drains the quota. & & & & & \\
\hline & & & & $(10 \%)$ & $(60 \%)$ & $(30 \%)$ \\
\hline \multirow[t]{3}{*}{18.} & The signal strength is not & & & 3 & 18 & 9 \\
\hline & stable during the teaching and & & & & & \\
\hline & learning process. & & & $(10 \%)$ & $(60 \%)$ & $(30 \%)$ \\
\hline \multirow[t]{3}{*}{19.} & Google Classroom is & 3 & 14 & 6 & 7 & \\
\hline & & & & & & \\
\hline & & $(10 \%)$ & $(46.7 \%)$ & $(20 \%)$ & $(23.3 \%)$ & \\
\hline \multirow[t]{2}{*}{10.} & I often do not focus during & & 12 & & 18 & \\
\hline & & & $(40 \%)$ & & $(60 \%)$ & \\
\hline
\end{tabular}


In utilizing Google Classroom, as seen in table 6, most of the students (90\%) found that Google Classroom didn't drain their quota and they found their signal was stable during the teaching and learning process. However, in utilizing, most of the students $(56,7 \%)$ found the application was quite complicated to use, then almost half of the students (40\%) did sometimes not focus during the learning process.

Table 7. The barriers faced by the students in utilizing Zoom

\begin{tabular}{|c|c|c|c|c|c|c|}
\hline \multirow[t]{2}{*}{ No. } & \multirow[t]{2}{*}{ Statement } & \multicolumn{5}{|c|}{ Zoom } \\
\hline & & SA & $\mathbf{A}$ & $\mathbf{N}$ & D & SD \\
\hline \multirow[t]{2}{*}{27.} & $\begin{array}{l}\text { The utilization of Zoom in the } \\
\text { teaching and learning process }\end{array}$ & 14 & 16 & & & \\
\hline & drains the quota. & $(46.7 \%)$ & $(53.3 \%)$ & & & \\
\hline \multirow[t]{2}{*}{28.} & $\begin{array}{l}\text { The signal strength is not stable } \\
\text { during the teaching and }\end{array}$ & 23 & 7 & & & \\
\hline & learning process. & $(76.7 \%)$ & $(23.3 \%)$ & & & \\
\hline \multirow[t]{2}{*}{29.} & Zoom is complicated to use. & & 13 & 8 & 9 & \\
\hline & & & $(43.3 \%)$ & $(26.7 \%)$ & $(30 \%)$ & \\
\hline \multirow[t]{2}{*}{30.} & $\begin{array}{l}\text { I often do not focus during the } \\
\text { learning process. }\end{array}$ & & 15 & 7 & 8 & \\
\hline & & & $(56.7 \%)$ & $(23,3 \%)$ & $(26,7 \%)$ & \\
\hline
\end{tabular}

Different from WhatsApp and Google Classroom as seen in table 7, all of the students found that the utilization of Zoom drained their quota and sometimes their signals were not stable. Moreover, almost half of the students felt this application was quite complicated to use. Then from these barriers, it sometimes made the student no focus during the learning and teaching process.

Table 8. The barriers faced by the students in utilizing Google Meet

\begin{tabular}{|c|c|c|c|c|c|c|}
\hline \multirow[t]{2}{*}{ No. } & \multirow[t]{2}{*}{ Statement } & \multicolumn{5}{|c|}{ Google Meet } \\
\hline & & SA & $\mathbf{A}$ & $\mathbf{N}$ & $\mathbf{D}$ & SD \\
\hline \multirow[t]{3}{*}{37.} & The utilization of Google Meet & 22 & 8 & & & \\
\hline & in the teaching and learning & & & & & \\
\hline & process drains the quota. & $(73.3 \%)$ & $(26.7 \%)$ & & & \\
\hline \multirow[t]{3}{*}{38.} & The signal strength is not stable & & 24 & & 6 & \\
\hline & during the teaching and & & & & & \\
\hline & learning process. & & $(80 \%)$ & & $(20 \%)$ & \\
\hline \multirow[t]{2}{*}{39.} & Google Meet is complicated to & & 14 & 6 & 10 & \\
\hline & & & $(46.7 \%)$ & $(20 \%)$ & $(33.3)$ & \\
\hline \multirow[t]{2}{*}{40.} & I often do not focus during the & & 15 & 8 & 7 & \\
\hline & learning process. & & $(50 \%)$ & $(26.7 \%)$ & $(23.3 \%)$ & \\
\hline
\end{tabular}

In line with WhatsApp, the students also found Google Meet was very draining their quota, so they sometimes encountered unstable signals during the teaching and learning process. 404 
Besides that, the students also felt that this application was quite difficult to use so that sometimes this made them not focus during the learning process.

\section{The Most Effective Application based on the Students' Experiences}

Regarding the e-learning applications that suitable for the students' needs and situation based on their experience, WhatsApp was the most effective and highly recommended since it was considered a friendly application for them and their gadgets. Besides this application was already familiar to them, in delivering teaching materials (text, file, link, photo, audio, and video), it could be shared easily within interaction through WhatsApp group. Moreover, besides it was easy to access and use, the students claimed that WhatsApp relatively worked well even under poor signal. while the other applications were not as well as WhatsApp.

\section{E. CONCLUSION}

The pandemic of Covid-19 has given a significant effect that inflicted policy changes in various sectors, including in the education field. This pandemic has forced the Indonesian government through its Ministry of Education and Culture to implement policies moving conventional classrooms to online classrooms. This condition forces the teachers and students to study from home. Some learning-based applications have been offered by the government to support online learning, such as WhatsApp, Zoom, Google Classroom, and Google Meet. This study concluded that the utilization of these applications can help the students to learn English virtually understand the material and complete the assignments given, Moreover, through the use of these applications, can help students to improve their digital literacy. Nevertheless, several obstacles faced by students in utilizing applications, such as limited quota, unstable signal strength, and some applications that are complicated to use. However, from these four applications that are often used in ELT in online learning, WhatsApp is the most effective and recommended application because this application is quite familiar to students. This application is very easy to access and use. Moreover, it is no drain much quota. Most users choose and use WhatsApp because it allows to the send message one another with a low cost (Rolve, 2013). The findings of this research described that the use of application in English language teaching and learning can be a media reference for the teacher to support the online learning. The teacher can choose the appropriate application based on the learning subject, teaching material, and teaching and learning activities. Furthermore, to avoid the problem such as technical problem and others during the learning process, the teacher also must consider the students' needs and conditions, so the teaching and learning process can run well. 


\section{REFERENCES}

Albitar S. (2020). Impelementasi Pembelajaran Daring Untuk Meningkatkan Mutu Pendidikan Sebagai Dampak Diterapkannya Social Distancing. Jurnal pendidikan bahasa dan sastra indonesia 5(1).

Bouhnik, D., \& Deshen, M. (2014). WhatsApp Goes to School: Mobile Instant Messaging between Teachers and Students. Journal of Information Technology Education: Research, 13, 217-231.

Bower, M., Dalgarno, B., Kennedy, G. E., Lee, M. J., \& Kenney, J. (2015). Design and Implementation Factors in Blended Synchronous Learning Environments: Outcomes from a CrossCase Analysis. Computers \& Education, 8(6).

Cakrawati, L.M. (2017). Students' Perceptions on the Use of Online Learning Platforms in EFL Classroom. English Language Teaching and Technology Journal (ELT-Tech Journal) Vol. 1 (1), $22-30$

D'Eca, T. A. (2003). The Use of Chat in EFL/ESL. Retrieved from: http://www.teslej.org/wordpress/issues/volume7/ej25/ej25int/

Evans, R. G., \& Sadler, E. J. (2008). Methods and Technologies to Improve Efficiency of Water Use. Water Resources Research. 44, 1-15.

Fakhruddin, A. (2018). Using Google Meet in Teaching Speaking. Journal of English Langage Learning (JELL), Vol. 2(2), 43-46. Retrieved from: https://www.jurnal.unma.ac.id/index.php/JELL/article/view/2220/1806

Guzacheva, N. (2020). Zoom Technology as an Effective Tool for Distance Learning in Teaching English to Medical Students. Bulletin of Science and Practice 6(5):457-460. Retrieved from: https://www.researchgate.net/publication/341445262 Zoom Technology as an Effective Tool for Distance Learning in Teaching English to Medical Students

Kheryadi. (2017). The Implementation of "Whatsapp" as A Media of English Language Teaching. LOQUEN, 10(2), 1-14. Retrieved from: https://media.neliti.com/media/publications/237570-the-implementation-ofwhatsapp-as-a-medi-f6caeb29.pdf

Khusaini., Suyudi, A., Winarto, \& Sugiyanto. (2017). Optimalisasi Penggunaan WhatsApp dalam Perkuliahan Penilaian Pendidikan Fisika. JRKPF UAD, 4(1), $1-7$.

Latif, S. (2016). Learning Engagement in Virtual Environment. International Journal of Computer Application, 148(11), 7-13. Retrieved from https://www.ijcaonline.org/archives/volume148/number11/25799- 2016911289.

Miming, Azminingsih (2019) Sikap Siswa dalam Penggunaan Aplikasi Whats App Dalam Pembelajaran Bahasa Inggris di SMA N 5 Padang. Sarjana thesis, STKIP PGRI Sumatera Barat.

Ni. (2020). Penggunaan Media Whatsapp, Google Classroom Dan Zoom Sebagai Alternatif Pembelajaran Daring Pendidikan Agama Hindu Dan Budi Pekerti Dimasa Pandemi Covid-19. Cetta: Jurnal Ilmu Pendidikan,3(3f). Retrieved from: http://jayapanguspress.penerbit.org/index.php/cetta/article/view/657 
Riyanti, E.D. \& Muslimah, A. (2018). A survey on the Use of Google Classroom in English Language Education Department of Islamic University of Indonesia. Retrieved from: https://dspace.uii.ac.id/handle/123456789/10932

Roida, P. \& Yuni, F. (2020) Analisa Pemanfaatan Teknologi Informasi Dalam Pembelajaran Jarak Jauh Di Tengah Pandemi Virus Corona Covid-19. Journal of Information System Applied, Management and Accounting Research, 4(2).

Rolfe, W. (2013). WhatsApp-Surpasses - 250 million active users. Retrieved from: http://blogswsi.com/digits/WhatsApp

Wahyu, A. F. D. (2020). Dampak Covid-19 Terhadap Implementasi Pembelajaran Daring Di Sekolah Dasar. Jurnal Ilmu Pendidikan 2(1).

Walker, L. (2020). 10 Best Mobile Messaging Apps of 2020. Retrieved from: https://www.lifewire.com/best-mobile-messaging-apps- 2654839 